\title{
Phytoecdysteroids from the Stem Bark of Vitex doniana and Their Anti-Inflammatory Effects
}

Authors

Affiliations
Charles O. Ochieng ${ }^{1}$, Ismail O. Ishola ${ }^{2}$, Sylvia A. Opiyo ${ }^{1}$, Lawrence A.O. Manguro ${ }^{1}$, Philip O. Owuor ${ }^{1}$, Keng-Chong Wong ${ }^{3}$

${ }^{1}$ Department of Chemistry, Maseno University, Maseno, Kenya

${ }^{2}$ Department of Pharmacology, Faculty of Basic Medical Sciences, College of Medicine, University of Lagos, Lagos, Nigeria

${ }^{3}$ School of Chemical Sciences, Universiti Sains Malaysia, Penang, Malaysia
Key words

- Vitex doniana

- Lamiaceae

- anti-inflammatory

- 21-hydroxyshidasterone

- 11-hydroxy-20-deoxyshidasterone

- 2,3-acetonide-24-hydroxyecdysone

\section{Abstract \\ $\nabla$}

With reference to the ethnopharmacological significance of Vitex doniana Sweet (Lamiaceae) leaves in the treatment of stomach and rheumatic pains as well as inflammatory disorders, biological studies on its stem bark extracts have also reported anti-inflammatory and analgesic activities, with no attempt to identify the active components. Chromatographic and spectroscopic procedures identified three new phytoecdysteroids: 21 -hydroxyshidasterone (1), 11 $\beta$-hydroxy20-deoxyshidasterone (2), and 2,3-acetonide-24hydroxyecdysone (3) from the stem bark methanol extracts along with known ecdysteroids shidasterone (4), ajugasterone C (5), 24-hydroxyecdysone (6), and 11 $\beta, 24$-hydroxyecdysone (7). The compounds $(1-7)$ showed significant $(p \leq 0.05)$ inhibitory effect at $100 \mathrm{mg} / \mathrm{kg}$ dose on rat paw oe-

\section{Introduction}

$\nabla$

received April 21, 2012

revised October 2, 2012

accepted October 8, 2012

Bibliography

DOI http://dx.doi.org/

$10.1055 / \mathrm{s}-0032-1327880$

Published online November 13, 2012

Planta Med 2013; 79: 52-59

(c) Georg Thieme Verlag KG

Stuttgart · New York .

ISSN 0032-0943

\section{Correspondence}

Dr. Charles Ochieng

Department of Chemistry

Maseno University

P.O Box 333

40104, Maseno

Kenya

Phone: + 254726915429

otieno.charles9@gmail.com
A number of Vitex species have been investigated as a source of potential bioactive compounds such as ecdysteroids [1], diterpenoids [2], iridoids [3], flavonoids, and phenolic compounds [4] demonstrating antioxidant, anti-inflammatory, antimicrobial, hepatoprotective, analgesic, antihistaminic, anti-implantation, and antiasthmatic activities [5,6]. Generally, ecdysteroids and iridoids have been explored as chemotaxonomic markers for the plants in the family Lamiaceae including Vitex species [7]. Vitex doniana Sweet (Lamiaceae) is a small to medium sized tree growing up to $25 \mathrm{~m}$ tall with no phytochemical report in spite of the available ethnopharmacological significance among different African communities [8], including use of water decoctions of different parts for treatment of stomach and rheumatic pains as well as inflammatory disorders $[9,10]$. Antidepressant effects and potentiation of sodi- dema development due to carrageenan-induced inflammation in Sprague Dawley rats. These results suggest a possible contribution of ecdysteroids to the anti-inflammatory effect of some V. doniana stem bark extracts.

\section{Abbreviations}

$\nabla$

m.a.s.l.: metres above sea level

b.w.: body weight

p.o.: per oral

i.p.: intraperitoneal

rel.: relative

$\mathrm{LD}_{50}$ : lethal dose for half the population

Supporting information available online at http://www.thieme-connect.de/ejournals/toc/ plantamedica

um thiopental sleeping time, muscle relaxant [11], anti-inflammatory, and analgesic activities [8] of $V$. doniana leaf extracts have been reported as well as antihypertensive effects on normative and hypertensive rats, trypanocidal and antidiarrheal activities of the stem bark [12]. Recent indication of anti-inflammatory, anticonvulsant, and antipyretic properties of ethanol extracts [13] of $V$. doniana stem bark prompted a phytochemical analysis of the plant's stem bark for potential anti-inflammatory compounds. As a result of this study, isolation of three new phytoecdysteroids [21-hydroxyshidasterone (1), 11 $\beta$-hydroxy20-deoxyshidasterone (2), and 2,3-acetonide-24hydroxyecdysone (3)] and four known phytoecdysteroids [shidasterone (4), ajugasterone C (5), 24-hydroxyecdysone (6), and 11 $\beta, 24$-dihydroxyecdysone (7)] with comparable anti-inflammatory activities as diclofenac are reported. 


\section{Materials and Methods}

$\nabla$

\section{Plant materials}

The stem bark of Vitex doniana Sweet was collected from the Mau Forest, Kenya $\left(0^{\circ} 29^{\prime} 07.70^{\prime \prime}\right.$; $34^{\circ} 44^{\prime}$ 02.28'E; elevation $4815 \mathrm{~m}$ a.s.1.). A voucher specimen (COO-VD-2010-02) was deposited at the University of Nairobi Herbarium, Department of Botany. Identification of the plant material was done by Mr. Patrick C. Mutiso of the Department of Botany, School of Biological Science of the University of Nairobi, Kenya.

\section{General instrumentation and chemicals}

Optical rotations were measured with a Perkin-Elmer 341 polarimeter, and UV spectra recorded with a Shimadzu UV 2101 PC spectrophotometer. NMR spectra were recorded on a Bruker Avance DRX-500 apparatus (500 MHz, $125 \mathrm{MHz}$ ) using either $\mathrm{CH}_{3} \mathrm{OH}-d_{4}$ or DMSO- $d_{6}$ and TMS as a reference for both carbon and proton. Mass spectra were performed with a Bruker Apex II mass spectrometer, while HRESIMS were recorded on a PEGSTAR ESI-MS/MS spectrometer. IR was performed using Perkin Elmer FTIR 600 series. Silica gel $60 \mathrm{~F}_{254}$ TLC plates (E. Merck) were used. Silica gel (Merck 60-120 Mesh ASTM) and MPLC [column: Spherisorb ODS 2-5 pm, $250 \times 4.6 \mathrm{~mm}$; detector: $254 \mathrm{~nm}$ ] were used in chromatographic separation. A plethysmometer (UgoBasile) was used for measuring the paw volume in experimental rats. Diclofenac (Total Heathcare), carrageenan (Sigma Chemicals Company), and standard rodent pellet (Livestock Feed PLC) were used in the anti-inflammatory experiment.

\section{Extraction and isolation}

Pulverised, dry stem bark (3 kg) was extracted successively with $n$-hexane and $\mathrm{MeOH}(5 \mathrm{~L})$ in a cold extraction apparatus. The concentrated $\mathrm{MeOH}$ extract $(120 \mathrm{~g})$ was diluted with $\mathrm{H}_{2} \mathrm{O}(1 \mathrm{~L})$, and the filtered dark brownish solution extracted successively with $\mathrm{CHCl}_{3}$, EtOAc, and $\mathrm{BuOH}$ (1 L each), using a continuous liquid-liquid extraction apparatus. Chromatographic separation on $n$-hexane extract was not successful and thus was not followed. $\mathrm{CHCl}_{3}$ extract ( $30 \mathrm{~g}$ ) was subjected to column chromatography (CC, $5 \times 100 \mathrm{~cm}$ column dimension) on silica gel ( $900 \mathrm{~g}, 0.063-$ $0.2 \mathrm{~mm}$ ) using $\mathrm{CHCl}_{3}-\mathrm{MeOH}$ as the eluent, with increasing $\mathrm{MeOH}$ content (100 mL fraction volumes each), and eight fractions collected were pooled into two main fractions according to TLC examination of the eluates ( $p$-anisaldehyde- $\mathrm{H}_{2} \mathrm{SO}_{4}-\mathrm{MeOH} ; 1: 1: 5$ ). The further purification of the first fraction $(12 \mathrm{~g})$ failed to yield pure isolates, while the second fraction $(10 \mathrm{~g})$ on repeated chromatography yielded $70 \mathrm{mg}$ of shidasterone $(4) ;\left(\mathrm{R}_{\mathrm{f}} 4: 0.63 \mathrm{CHCl}_{3}\right.$ : $\mathrm{MeOH} \mathrm{4:1).}$

The EtOAc fraction ( $47 \mathrm{~g})$ was subjected to $\mathrm{CC}(5 \times 100 \mathrm{~cm})$ on silica gel $(1.2 \mathrm{~kg}, 0.063-0.2 \mathrm{~mm})$ using $\mathrm{CHCl}_{3}-\mathrm{MeOH}$ as the eluent, with increasing $\mathrm{MeOH}$ content to obtain fifteen fractions $(150 \mathrm{~mL})$ which were pooled into three major fractions according to their TLC profiles. Fraction 1 ( $21 \mathrm{~g}$ ), eluted with $\mathrm{CHCl}_{3}-\mathrm{MeOH}$ (19:1 to 9:1), was rechromatographed on silica gel CC (0.063$0.2 \mathrm{~mm}, 5 \times 50 \mathrm{~cm}, 50 \mathrm{~mL}$ fractions) to afford two major fractions ( $1 \mathrm{a}$ and $1 \mathrm{~b} ; 160 \mathrm{mg}$ and $10 \mathrm{~g}$, respectively) indicating two distinct TLC profiles up on spray with $p$-anisaldehyde reagent. The fraction 1a (150 mg) was further purified by MPLC [column: Spherisorb ODS 2-5 pm, $250 \times 4.6 \mathrm{~mm}$; mobile phase: $\mathrm{MeOH}-\mathrm{H}_{2} \mathrm{O}$ (1:1); flow rate: $1.0 \mathrm{~mL} / \mathrm{min} ; 50-60 \mathrm{~mL}$ fraction volume; detector: $254 \mathrm{~nm}$ ] to furnish $32 \mathrm{mg}$ of $11 \beta$-hydroxy-20-deoxyshidasterone $(2)\left(t_{R}: 45-50 \mathrm{~min}\right)$ and $41 \mathrm{mg}$ of 2,3-acetonide-24-hydroxyecdysone $(3)\left(t_{R}: 60-65 \mathrm{~min}\right)$. About $84 \mathrm{mg}$ of 3 was ob- tained from fraction 1b through fractional precipitation as a white amorphous solid. Fraction 2 (432 mg), eluted with $\mathrm{CHCl}_{3}$ $\mathrm{MeOH}$ (17:3 to $4: 1$ ), crystallised in $\mathrm{MeOH}-E t O A c$ to afford $102 \mathrm{mg}$ of 24-hydroxyecdysone (6) ( $\mathrm{R}_{\mathrm{f}}: 0.52 \mathrm{CHCl}_{3}$ : $\left.\mathrm{MeOH}, 4: 1\right)$ as colourless needle-like crystals. The mother liquor afforded $61 \mathrm{mg}$ 21-hydroxyshidasterone (1) ( $\left.t_{\mathrm{R}}: 60-70 \mathrm{~min}\right)$ after MPLC (same conditions described earlier) purification and crystallisation in MeOH-EtOAc. A white amorphous solid precipitated from fraction 3 eluted with $\mathrm{CHCl}_{3}-\mathrm{MeOH}$ ( $4: 1$ to $7: 3$ ), which was then triturated using hot $\mathrm{MeOH}$ several times to afford $43 \mathrm{mg}$ as a mixture of 6 and ajugasterone (5) $\left(\mathrm{R}_{\mathrm{f}}: 0.44 \mathrm{CHCl}_{3}: \mathrm{MeOH} 4: 1\right)$. The $n$ $\mathrm{BuOH}$ extract (34 g) was chromatographed on silica gel CC (900 g, 0.063-0.2 mm, $5 \times 100 \mathrm{~cm}$ ) using $\mathrm{CHCl}_{3}-\mathrm{MeOH}$ as the eluent and adjusting the polarity with $\mathrm{MeOH}$ to obtain twenty fractions which were pooled into three major fractions according to their TLC profile visualised using $p$-anisaldehyde reagent. The first fractions contained the previously isolated compounds from the EtOAc extracts, 1 (102 mg), 5 (59 mg), and 6 (67 mg), while the second fractions (361 mg) were subjected to reverse-phase MPLC (same conditions as described earlier) to yield $5(153 \mathrm{mg})$ and 11 $\beta, 24$-dihydroxyecdysone (7) [ $\mathrm{R}_{\mathrm{t}}:$ 65-70 min; (86 mg)].

Compound 1 (21-hydroxyshidasterone $\{($ rel. $2 \beta, 3 \beta, 5 \beta, 22 \mathrm{R})-22,25$ epoxy-2,3,14,20,21-pentahydroxycholest-7-en-6-one\}): white crystalline solid (MeOH: EtOAc); m.p. 232-234 ${ }^{\circ} \mathrm{C}$ (uncorrected); $\mathrm{R}_{\mathrm{f}} 0.42$ silica gel $60 \mathrm{~F}_{254}\left(\mathrm{CHCl}_{3} / \mathrm{MeOH}, 4: 1\right) ;[\alpha]_{\mathrm{D}}^{25}=+13(c=0.1$ $\mathrm{MeOH}) ; \mathrm{UV}(\mathrm{MeOH}) \lambda_{\max }(\log \varepsilon) 249$ (2.34); IR (KBr) $v_{\max } 3448$, 2968, 1652, 1514, $1057 \mathrm{~cm}^{-1} ;{ }^{1} \mathrm{H}$ and ${ }^{13} \mathrm{C}$ NMR $\left(\mathrm{CD}_{3} \mathrm{OD}, 500\right.$, $125 \mathrm{MHz}$ ), see Table 1; ESI-MS (rel. int): $479\left(50[\mathrm{M}+\mathrm{H}]^{+}\right) 461$ $\left(40\left[\mathrm{M}+\mathrm{H}-\mathrm{H}_{2} \mathrm{O}\right]^{+}\right), 443\left(40,\left[\mathrm{M}+\mathrm{H}-2 \mathrm{H}_{2} \mathrm{O}\right]^{+}\right), 425(35,[\mathrm{M}+\mathrm{H}-$ $\left.\left.3 \mathrm{H}_{2} \mathrm{O}\right]+\right), 407\left(100,\left[\mathrm{M}+\mathrm{H}-4 \mathrm{H}_{2} \mathrm{O}\right]^{+}\right), 380\left(60,\left[\mathrm{M}+\mathrm{H}-\mathrm{C}_{6} \mathrm{H}_{11} \mathrm{O}, \mathrm{C}_{20} /\right.\right.$ $\left.\left.\mathrm{C}_{22}\right]^{+}\right), 362\left(30, \quad\left[\mathrm{M}+\mathrm{H}-\mathrm{C}_{6} \mathrm{H}_{11} \mathrm{O}-\mathrm{H}_{2} \mathrm{O}\right]^{+}\right), 344 \quad(65,[\mathrm{M}+$ $\left.\left.\mathrm{H}-\mathrm{C}_{6} \mathrm{H}_{11} \mathrm{O}-2 \mathrm{H}_{2} \mathrm{O}\right]^{+}\right), 326\left(35,\left[\mathrm{M}+\mathrm{H}_{-} \mathrm{C}_{6} \mathrm{H}_{11} \mathrm{O}-3 \mathrm{H}_{2} \mathrm{O}\right]^{+}\right), 308(30,[\mathrm{M}$ $\left.+\mathrm{H}_{-} \mathrm{C}_{6} \mathrm{H}_{11} \mathrm{O}-4 \mathrm{H}_{2} \mathrm{O}\right]^{+}$); HR-ESI-MS (ToF) $m / z$ : 501.2096 (calcd. $501.2189[\mathrm{M}+\mathrm{Na}]^{+}$).

Compound 2 (11 $\beta$-hydroxy-20-deoxyshidasterone $\{$ (rel. $2 \beta, 3 \beta, 5 \beta, 11 \beta, 22 \mathrm{R}) \quad 22,25$-epoxy-2,3,11,14-tetrahydroxycholest7-en-6-one $)$ ): white powder $\left(\mathrm{CHCl}_{3} / \mathrm{MeOH}\right) ;$ m.p. $258-262{ }^{\circ} \mathrm{C}$ (uncorrected); $\mathrm{R}_{\mathrm{f}} 0.65$ silica gel $60 \mathrm{~F}_{254}\left(\mathrm{CHCl}_{3} / \mathrm{MeOH}, 4: 1\right)$; $[\alpha]_{\mathrm{D}}^{25}=+7(c=0.01 \mathrm{MeOH}) ; \mathrm{UV}(\mathrm{MeOH}) \lambda_{\max }(\log \varepsilon) 241$ (3.54); IR $(\mathrm{KBr}) v_{\max } 3427,2832,1654,1059 \mathrm{~cm}^{-1} ;{ }^{1} \mathrm{H}$ and ${ }^{13} \mathrm{C}$ NMR $\left(\mathrm{CD}_{3} \mathrm{OD}, 500,125 \mathrm{MHz}\right.$ ), see $\bigcirc$ Table 1; ESI-MS (rel. int) 463 (60, $\left.[\mathrm{M}+\mathrm{H}]^{+}\right), 445\left(100,\left[\mathrm{M}+\mathrm{H}-\mathrm{H}_{2} \mathrm{O}\right]^{+}\right), 427\left(30,\left[\mathrm{M}+\mathrm{H}-2 \mathrm{H}_{2} \mathrm{O}\right]^{+}\right)$, 409 (60, [M + H-3 $\left.\mathrm{H}_{2} \mathrm{O}\right]^{+}$); HR-ESI-MS (ToF) m/z: 463.3591 (calcd. $\left.463.3454[\mathrm{M}+\mathrm{H}]^{+}\right), 485.2651\left(\right.$ calcd. $\left.485.2636[\mathrm{M}+\mathrm{Na}]^{+}\right)$.

Compound 3 (2,3-acetonide-24-hydroxyecdysone $\{$ rel. $2 \beta, 3 \beta$-acetonide-14 $\alpha, 22 \mathrm{R}, 24,25$-tetrahydroxycholest-7-en-6-one $\})$ : white needles crystals $(\mathrm{MeOH}) ;$ m.p $158-160^{\circ} \mathrm{C}$ (uncorrected); $\mathrm{R}_{\mathrm{f}} 0.78$ silica gel $60 \mathrm{~F}_{254}\left(\mathrm{CHCl}_{3} / \mathrm{MeOH}, 4: 1\right) ;[\alpha]_{\mathrm{D}}^{25}=+56.4(c=0.9 \mathrm{MeOH})$; $\mathrm{UV}(\mathrm{MeOH}) \lambda_{\max }(\log \varepsilon) 244$ (3.95) nm; IR (KBr) $v_{\max } 3423,2937$, 1653, 1462, 1376, $1050 \mathrm{~cm}^{-1} .{ }^{1} \mathrm{H}$ and ${ }^{13} \mathrm{C}$ NMR $\left(\mathrm{CD}_{3} \mathrm{OD}, 500\right.$, $125 \mathrm{MHz}$ ), see Table 1; ESI-MS (rel. int): $520.7\left(20,[\mathrm{M}]^{+}\right), 502$ $\left(5,\left[\mathrm{M}-\mathrm{H}_{2} \mathrm{O}\right]^{+}\right), 484\left(25,\left[\mathrm{M}-2 \mathrm{H}_{2} \mathrm{O}\right]^{+}\right), 466\left(5,\left[\mathrm{M}-3 \mathrm{H}_{2} \mathrm{O}\right]^{+}\right), 448$ $\left(2,\left[\mathrm{M}-4 \mathrm{H}_{2} \mathrm{O}\right]^{+}\right), 360\left(50,\left[\mathrm{M}+\mathrm{H}-\mathrm{C}_{20}-\mathrm{C}_{29} \mathrm{C}_{8} \mathrm{H}_{17} \mathrm{O}_{3}\right]^{+}\right), 342(80$, $\left.\left[\mathrm{M}+\mathrm{H}-\left(\mathrm{C}_{8} \mathrm{H}_{17} \mathrm{O}_{3}+\mathrm{H}_{2} \mathrm{O}\right)\right]^{+}\right), 300\left(100,\left[\mathrm{M}+\mathrm{H}-\left(\mathrm{C}_{8} \mathrm{H}_{17} \mathrm{O}_{3}+\mathrm{CH}_{3} \mathrm{C}-\right.\right.\right.$ $\left.\left.\left.+\mathrm{H}_{2} \mathrm{O}\right)\right]^{+}\right), 282\left(20,\left[\mathrm{M}+\mathrm{H}-\left(\mathrm{C}_{8} \mathrm{H}_{17} \mathrm{O}_{3}+\mathrm{CH}_{3} \mathrm{C}-+2 \mathrm{H}_{2} \mathrm{O}\right)\right]^{+}\right), 161(40$, $\left.\left[\mathrm{C}_{8} \mathrm{H}_{17} \mathrm{O}_{3}\right]^{+}\right), 125\left(30,\left[\mathrm{C}_{8} \mathrm{H}_{17} \mathrm{O}_{3}-2 \mathrm{H}_{2} \mathrm{O}\right]^{+}\right)$; HR-ESI-MS (ToF) $\mathrm{m} / \mathrm{z}$ : 543.4561 (calcd. $543.4560[\mathrm{M}+\mathrm{Na}]^{+}$).

\section{Anti-inflammatory activity}

Sprague Dawley rats (140-170 g) of either sex used in this study were obtained from the Laboratory Animals Centre of the College of Medicine, University of Lagos, Nigeria. The animals were kept 
Table 1 Effect of crude fractions from Vitex doniana stem bark on carrageenan-induced paw oedema.

\begin{tabular}{|c|c|c|c|c|c|c|}
\hline \multirow[t]{2}{*}{ Treatment } & \multicolumn{6}{|c|}{ Increase in paw circumference $(\mathrm{cm})$ and percent inhibitions of paw oedema } \\
\hline & $\mathbf{T}_{1 \mathrm{~h}}$ & $\mathrm{~T}_{2 \mathrm{~h}}$ & $\mathrm{~T}_{3 \mathrm{~h}}$ & $\mathbf{T}_{4 \mathrm{~h}}$ & $T_{5 h}$ & $\mathrm{~T}_{6 \mathrm{~h}}$ \\
\hline$n$-Saline $\mathrm{H}_{2} \mathrm{O}$ & $0.62 \pm 0.08$ & $0.80 \pm 0.10$ & $0.90 \pm 0.11$ & $0.98 \pm 0.19$ & $1.04 \pm 0.15$ & $0.72 \pm 0.14$ \\
\hline $\begin{array}{l}\mathrm{CHCl}_{3-} \\
\text { extract }\end{array}$ & $\begin{array}{l}0.34 \pm 0.01^{\mathrm{a}} \\
(45.16 \%)\end{array}$ & $\begin{array}{l}0.37 \pm 0.06^{a} \\
(53.75 \%)\end{array}$ & $\begin{array}{l}0.35 \pm 0.05^{\mathrm{b}} \\
(61.11 \%)\end{array}$ & $\begin{array}{l}0.41 \pm 0.04^{\alpha \alpha} \\
(58.16 \%)\end{array}$ & $\begin{array}{l}0.38 \pm 0.05^{b \alpha} \\
(63.46 \%)\end{array}$ & $\begin{array}{l}0.23 \pm 0.05^{\circ} \\
(68.06 \%)\end{array}$ \\
\hline $\begin{array}{l}\text { EtOAc } \\
\text { extract }\end{array}$ & $\begin{array}{l}0.33 \pm 0.07^{a} \\
(46.77 \%)\end{array}$ & $\begin{array}{l}0.39 \pm 0.03^{a} \\
(51.25 \%)\end{array}$ & $\begin{array}{l}0.45 \pm 0.03^{a \alpha} \\
(50.00 \%)\end{array}$ & $\begin{array}{l}0.35 \pm 0.04^{\mathrm{a}} \\
(64.29 \%)\end{array}$ & $\begin{array}{l}0.37 \pm 0.05^{b \alpha} \\
(64.42 \%)\end{array}$ & $\begin{array}{l}0.21 \pm 0.05 \\
(70.83 \%)\end{array}$ \\
\hline $\begin{array}{l}n-\mathrm{BuOH} \\
\text { extract }\end{array}$ & $\begin{array}{l}0.34 \pm 0.07^{\mathrm{a}} \\
(45.16 \%)\end{array}$ & $\begin{array}{l}0.49 \pm 0.08^{a} \\
(38.75 \%)\end{array}$ & $\begin{array}{l}0.44 \pm 0.10^{\mathrm{a}} \\
(51.11 \%)\end{array}$ & $\begin{array}{l}0.45 \pm 0.03^{\alpha \beta} \\
(54.08 \%)\end{array}$ & $\begin{array}{l}0.33 \pm 0.09^{b} \\
(68.27 \%)\end{array}$ & $\begin{array}{l}0.20 \pm 0.01 \\
(72.22 \%)\end{array}$ \\
\hline Diclofenac & $\begin{array}{l}0.33 \pm 0.02^{\mathrm{a}} \\
(46.77 \%)\end{array}$ & $\begin{array}{l}0.45 \pm 0.11^{\mathrm{a}} \\
(43.75 \%)\end{array}$ & $\begin{array}{l}0.31 \pm 0.02^{b} \\
(65.56 \%)\end{array}$ & $\begin{array}{l}0.26 \pm 0.01^{b} \\
(73.47 \%)\end{array}$ & $\begin{array}{l}0.21 \pm 0.01^{b} \\
(79.81 \%)\end{array}$ & $\begin{array}{l}0.13 \pm 0.01^{1} \\
(81.94 \%)\end{array}$ \\
\hline
\end{tabular}

Values are mean \pm SEM $(n=5)$; ${ }^{a} p<0.05,{ }^{b} p<0.01$ vs. control; ${ }^{\alpha} \mathrm{p}<0.05,{ }^{\beta} \mathrm{p}<0.01$ (two-way ANOVA followed by Bonferroni multiple comparison tests). Figures in parenthesis indicate inhibition (\%) of oedema development. Extracts' dosage $=100 \mathrm{mg} / \mathrm{kg} ; 0.9 \%$ normal saline water $=10 \mathrm{~mL} / \mathrm{kg}$

in well-ventilated and hygienic compartments maintained under standard environmental conditions and fed with standard rodent pellet and water ad libitum. The experimental protocol CM/COM/ 8/Vol. XXI used in this study was approved by the Research Grants and Experimentation Ethics Committee of the College of Medicine, University of Lagos, Nigeria on the 12th December, 2011. All the procedures conformed to the guide for the care and use of animals in research and teaching published by the University of Lagos, Nigeria.

\section{Acute toxicity and lethality test}

The acute toxicity and lethality $\left(\mathrm{LD}_{50}\right)$ of $V$. doniana extracts in rats $(n=15)$ were estimated using the method described by Lorke [14]. In the first trial, animals received oral administration of 10 , 100 , and $1000 \mathrm{mg} / \mathrm{kg}(\mathrm{n}=5)$ of $V$. doniana extracts and were observed for $24 \mathrm{~h}$. Since no death occurred in any of the groups in the first stage of the test, 1500,2500 , and $5000 \mathrm{mg} / \mathrm{kg}$ doses of the extract were administered to a fresh batch of animals $(n=5)$, and no lethality or behaviour changes were observed within $24 \mathrm{~h}$. A repeat of the test with a fresh batch of animals using the intraperitoneal (i.p.) route also indicated no lethality. Thus, the oral and i.p. $\mathrm{LD}_{50}$ values in rats were found to be greater than $5000 \mathrm{mg} / \mathrm{kg}$, indicating a lack of acute toxicity.

\section{Carrageenan-induced rat paw oedema}

Sprague Dawley rats (140-170 g) of either sex were randomly divided into groups of 5 animals each and were used after a 12-h fast but allowed free access to water except during the experiment. The crude fractions $(100 \mathrm{mg} / \mathrm{kg}$ ) and compounds [1-7] (90\% pure analytical TLC conditions) from $V$. doniana stem bark (100 mg/kg/bw. p.o.), diclofenac $50 \mathrm{mg} / \mathrm{kg}$, p.o. (reference drug, $99 \%$ pure ISO $9001: 2000$ ), and $0.05 \%$ DMSO in normal saline $10 \mathrm{~mL} / \mathrm{kg}, \mathrm{p} . \mathrm{o}$. (control) were administered one hour before subcutaneous injection of $100 \mu \mathrm{L}$ of carrageenan $(1 \% \mathrm{w} / \mathrm{v}$ in $0.9 \%$ normal saline) into the callus of the right hind paw of the animal [15]. The linear paw circumference was measured using the cotton thread method immediately before injection of the phlogistic agent and at $1 \mathrm{~h}$ intervals for $6 \mathrm{~h} \mathrm{[15].}$ Inhibition $(\%)=\frac{\text { Increase in paw oedema }[\text { control] }- \text { Increase in paw oedema [treated] }}{\text { Increase in paw oedema }[\text { control] }} \times 100$

\section{Statistical analysis}

Results obtained were expressed as mean \pm standard error of mean (SEM). The data were analysed using one-way analysis of variance (ANOVA) followed by Bonferroni post-tests.

\section{Supporting information}

${ }^{1} \mathrm{H}$ NMR, ${ }^{13} \mathrm{C}$ NMR, and ESIMS spectra of compounds 1-3, HSQC, HMBC, and NOE spectra of compounds $\mathbf{1}$ and $\mathbf{2}$, as well as IR spectra of compounds $\mathbf{1}$ and $\mathbf{3}$ are shown as Supporting Information.

\section{Results and Discussion}

Injection of carrageenan into the sub-plantar tissue of the right hind paw of rats in the control group caused oedema development which peaked (1.04 \pm 0.15 , increase in paw circumference) at $5 \mathrm{~h}$ post-phlogistic injection ( Table 1 ). The effect of $V$. doniana extracts $(100 \mathrm{mg} / \mathrm{kg})$ was observed from the 3rd to the 6 th $\mathrm{h}$ with peak effects $(68.06,70.83$, and $72.22 \%$ inhibition) produced by all three extracts, chloroform, ethyl acetate, and $n$ butanol, respectively at the 6th hour. These effects were less than but not significantly different $(\mathrm{p} \leq 0.05)$ from that produced by $20 \mathrm{mg} / \mathrm{kg}$ diclofenac (81.94\%). In the course of this study, the entire partitioned fractions from the methanol extracts of $V$. doniana stem bark exhibited comparable reduction in carrageenan-induced paw oedema formation in rats, suggesting similar bioactive components in the fractions. As an effort to identify the bioactive substances, chromatographic separation and purifications resulted in the isolation of three new ecdysteroids, 21hydroxyshidasterone (1), 11-hydroxy-20-deoxyshidasterone (2), and 2,3-acetonide-24-hydroxyecdysone (3) together with four known ecdysteroids identified as shidasterone (4) [16], ajugasterone C (5) [1], 24-hydroxyecdysone (6) [17], and 11ß,24-dihydroxyecdysone (7) [1] based on their spectral data (MS and NMR) that corresponded to the previously published data ( Fig. 1). These seven ecdysteroids were identified as the major components from the stem bark of $V$. doniana among other minor components not identified in this study. Analysis of phytoecdysteroids among Vitex species has shown the occurrence of the three common (C-27, C-28, and C-29) ecdysteroids skeletal types [7].

Compounds 1 and 2, both white crystalline solids, displayed greenish grey spots upon spraying with $p$-anisaldehyde on a TLC plate comparable to the spot for 6 signifying structural similarities. Compound 1 gave an ESI-MS molecular ion peak at $m / z 479$ consistent with the molecular formula $\mathrm{C}_{27} \mathrm{H}_{42} \mathrm{O}_{7}$, confirmed by the HR-ESI-MS pseudomolecular ion at $m / z 501.2197[\mathrm{M}+\mathrm{Na}]^{+}$ (calcd. 501. $2189[\mathrm{M}+\mathrm{Na}]^{+} \mathrm{C}_{27} \mathrm{H}_{42} \mathrm{O}_{7}$ ). The characteristic fragment ions were formed from the intact parent compound by the loss of water: $m / z 461\left[\mathrm{M}+\mathrm{H}-\mathrm{H}_{2} \mathrm{O}\right]^{+}, 443\left[\mathrm{M}+\mathrm{H}-2 \mathrm{H}_{2} \mathrm{O}\right]^{+}$, and 425 


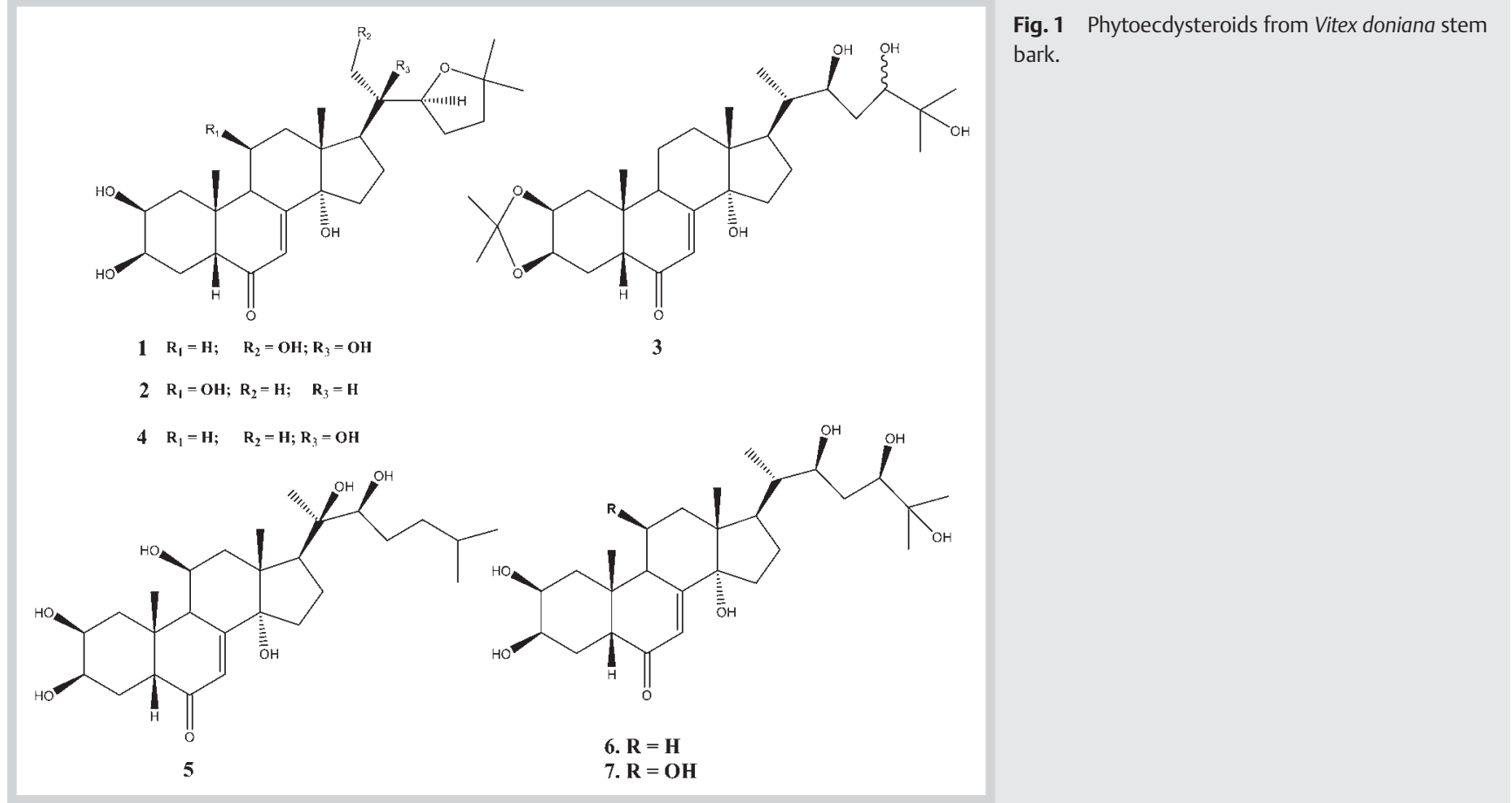

$\left[\mathrm{M}+\mathrm{H}-3 \mathrm{H}_{2} \mathrm{O}\right]^{+}$, which is a common feature in ecdysteroids mass spectra [18]. In the IR spectrum, it showed a strong absorption of hydroxyl groups at $3448 \mathrm{~cm}^{-1}$ and characteristic absorption of an $\alpha, \beta$-unsaturated carbonyl moiety at $1652 \mathrm{~cm}^{-1}$. Compound 2 showed UV absorption maxima at $\lambda_{\max } 241 \mathrm{~nm}$, which was in accordance with the presence of the 7-en-6-one chromophore of ecdysteroids. A molecular ion peak at $\mathrm{m} / \mathrm{z} 463.6188\left([\mathrm{M}+\mathrm{H}]^{+}\right.$, calcd. 463. $2981[\mathrm{M}+\mathrm{H}]^{+}$) and pseudomolecular ion peaks at 485.2652 [M + Na $]^{+}$(calcd. 485.2635 $[\mathrm{M}+\mathrm{Na}]^{+}$) of the compound indicated a molecular formula of $\mathrm{C}_{27} \mathrm{H}_{42} \mathrm{O}_{6}$, in accordance with the ${ }^{1} \mathrm{H}$ - and ${ }^{13} \mathrm{C}$-NMR data ( Table 2 ). In the IR spectrum, it showed strong absorption of hydroxyl groups at 3427 and $1059 \mathrm{~cm}^{-1}$ and characteristic absorption of the $\alpha, \beta$-unsaturated keto group at $1654 \mathrm{~cm}^{-1}$. Compound 3, isolated as white needles, displayed a UV spectrum $\lambda_{\max } 244 \mathrm{~nm}$ ) and IR spectrum with prominent absorption bands at $3423 \mathrm{~cm}^{-1}$ and $1653 \mathrm{~cm}^{-1}$, confirming the presence of a 7-en-6-keto group on the hydroxylated steroid nucleus. The ESIMS of 3 revealed a peak at $m / z 520.7$ for $[\mathrm{M}]^{+}$, which is consistent with the molecular formula $\mathrm{C}_{30} \mathrm{H}_{48} \mathrm{O}_{7}$, confirmed by an HR-ESI-MS peak at $\mathrm{m} / z 543.4561$ (calcd. $\left.543.4566[\mathrm{M}+\mathrm{Na}]^{+}\right)$. In the ESI mass spectrum, the peaks at $m / z$ $502,484,466,448$ corresponded to successive loss of four molecules of water from the parent molecular ion.

For the signal assignment, four methyl signals appearing as singlets were indentified in the ${ }^{1} \mathrm{H}$ NMR ( Table 2 ) spectrum of compound 1 contrary to the expected five methyl groups for the majority of the ecdysteroids. Such an observation implied an oxygenation of one of the side chain methyl groups (C-26/C-27 or C-21). The characteristic HMBC correlations ( Fig. 2) of the methyl groups through two and three bonds were utilised in the assignments of the germinal Me-26 $\left(\delta_{\mathrm{H}} 1.28,2 \mathrm{H}, \mathrm{s}\right)$ and Me-27 $\left(\delta_{\mathrm{H}} 1.28,2 \mathrm{H}, \mathrm{s}\right)$ groups owing to their mutual HMBC correlation, indicating a lack of oxygenation on $\mathrm{C}-26 / \mathrm{C}-27$. The differentiation between Me-19 $\left(\delta_{\mathrm{H}} 1.05,3 \mathrm{H}, \mathrm{s}\right)$ and Me-18 $\left(\delta_{\mathrm{H}} 0.98,3 \mathrm{H}, \mathrm{s}\right)$ atoms of the angular methyl groups was achieved by considering the $3 \mathrm{~J}$ correlation of the latter with C-17. Appearance of a doublet signal at $\delta_{\mathrm{H}} 3.54(1 \mathrm{H}, J=12 \mathrm{~Hz})$ coupling to another doublet overlapping with a solvent signal at $\delta_{\mathrm{H}} 3.41(1 \mathrm{H}, J=12 \mathrm{~Hz})$ in the ${ }^{1} \mathrm{H}$ NMR spectrum and $\mathrm{HMBC}$ cross-peaks detected between the same signal and ${ }^{13} \mathrm{C}$ NMR signal $\left(\delta_{\mathrm{C}} 50.8\right)$ ascribed for $\mathrm{C}-17$ suggested an oxymethylene proton on $\mathrm{C}-21$. The ${ }^{13} \mathrm{C}$ NMR chemical shift values ( Table 2) of C-22 (84.0) and C-25 (82.5) and the H-22/Me-26 NOE correlation ( Fig. 2 ) proved the presence of $\mathrm{OR}(\mathrm{R} \neq \mathrm{H})$ and a five-membered ring unit in the side chain [19]. Further support of this structure was achieved from the comparison of its spectral data with those of shidasterone $[16,18]$ except for the absence of one methyl (Me-21) instead of the oxymethylene signals observed in 1. Analysis of ${ }^{1} \mathrm{H}$ NMR spectral features and relative positions of $\mathrm{H}-2, \mathrm{H}-3, \mathrm{H}-5, \mathrm{H}-7, \mathrm{H}-9$, and $\mathrm{H}-17$, as well as those of Me-18 and Me-19 of 1 and 2 were almost identical. However, a notable difference was observed with the presence of a methyl doublet $\left[\delta_{\mathrm{H}} 0.92 \mathrm{~d}(3 \mathrm{H}, J=6.5 \mathrm{~Hz}, \mathrm{H}-21)\right]$ and an additional oxymethine proton $\left[\delta_{\mathrm{H}} 3.76 \mathrm{~m}(1 \mathrm{H}, \mathrm{H}-11)\right]$ in the ${ }^{1} \mathrm{H}$ NMR spectrum. Assuming the structure of compound 2, the methyl doublet could possibly exist at C-21, implying 20-deoxyshidasterone. C-11 has been observed to be a biosynthetically labile hydroxylation point in ecdysteroids [19-21], with cyclisation of the side chain to the tetrahydrofuran; attachment of a hydroxyl group at C-11 was the other possible difference between the two compounds. Moreover, the downfield shift observed for many signals in the ${ }^{1} \mathrm{H}$ NMR spectrum was attributed to the introduction of an 11-hydroxyl group to the ecdysteroid molecule [21]. Significant and diagnostic shifts were observed by the presence of a carbinol proton signal around $\delta_{\mathrm{H}} 4.32$ and downfield shifts of $\mathrm{H}-9$ and $\mathrm{H}-12_{\mathrm{ax}}$ of ca. 0.10 and 0.22 , respectively ( $\odot$ Table 2 ). Further downfield shifts of the remote protons by ca. +0.32 and +0.4 were also observed for $\mathrm{H}-1_{\mathrm{eq}}$ and $\mathrm{H}-12_{\mathrm{eq}}$, respectively, as compared to those of compound 1. It was noted that the presence of an 11-hydroxyl group caused $\mathrm{a}+2.1$ downfield shift of the $\mathrm{C}-1$ resonance, in addition to the expected downfield shift of the $\mathrm{C}-11$ resonance in the ${ }^{13} \mathrm{C}$ NMR spectrum. Significant downfield shifts were also ob- 


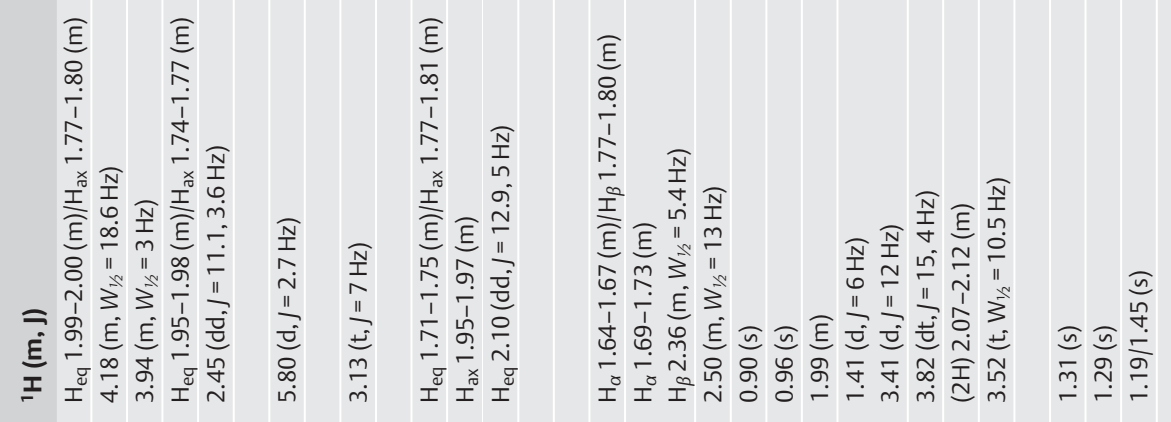

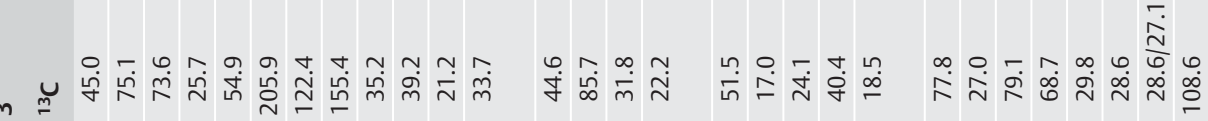

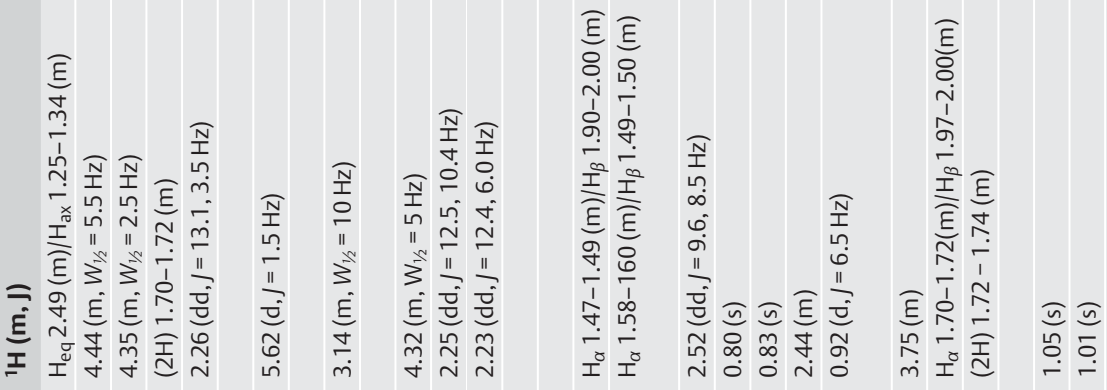

竞

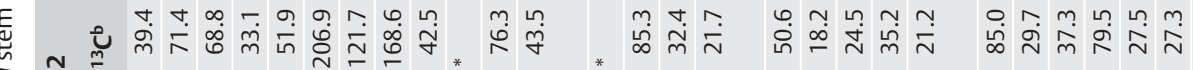

हू

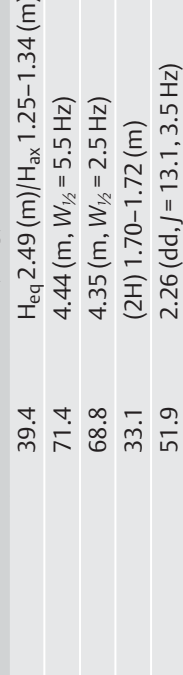

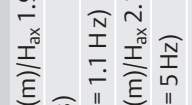

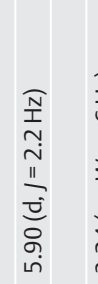

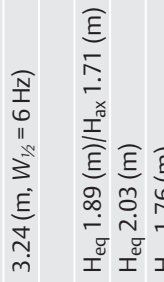

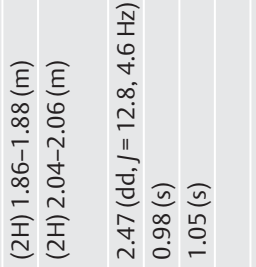

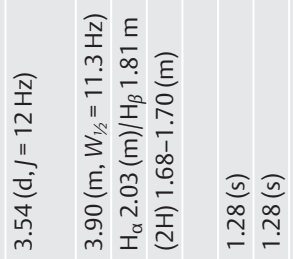

它

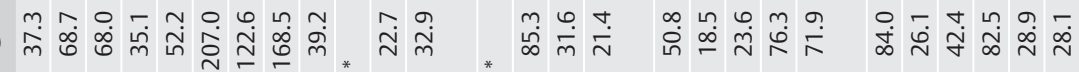

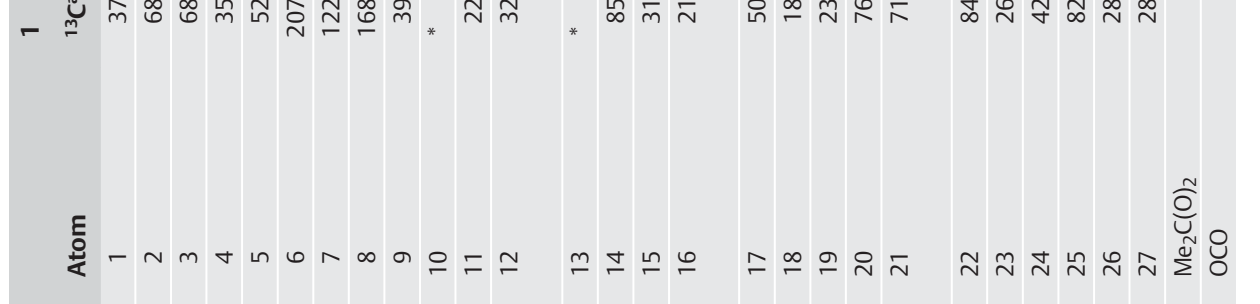




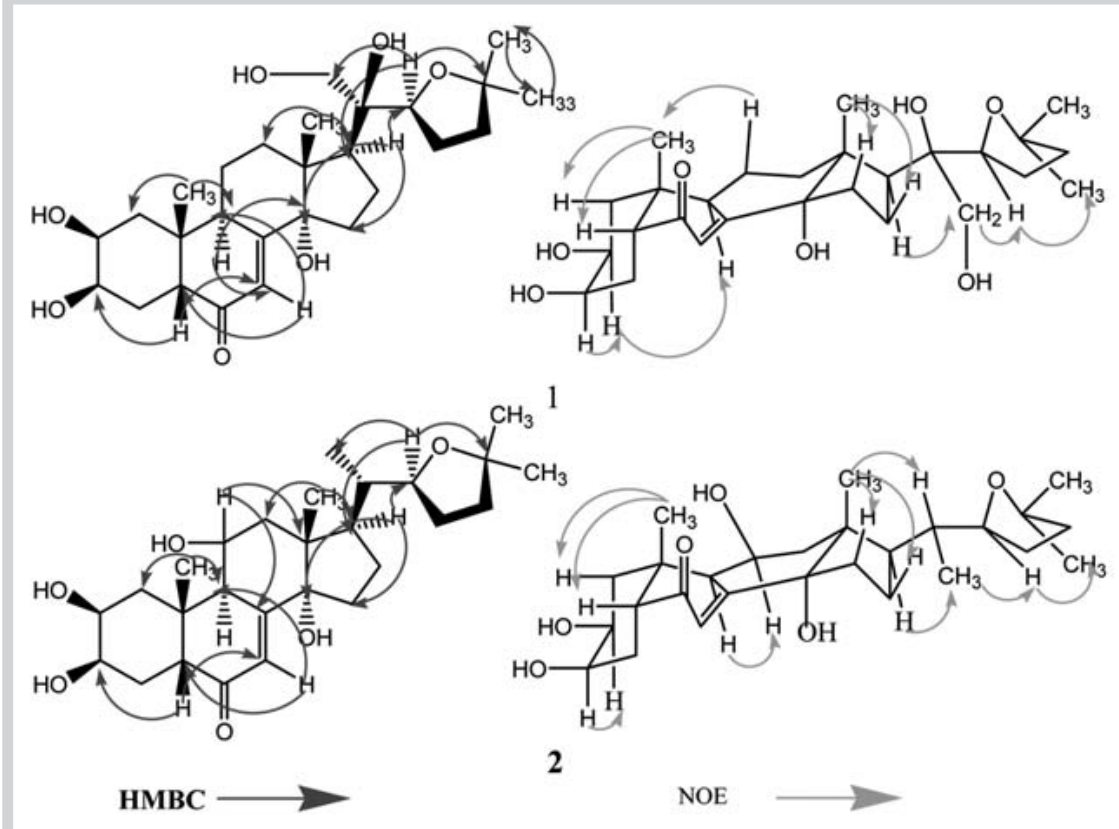

Fig. 2 Significant HMBC and NOE correlations of compounds $\mathbf{1}$ and $\mathbf{2}$.

served for C-9 and C-12 signals (ca. + 3.3 and 10.6, respectively) in the ${ }^{13} \mathrm{C}$ NMR spectrum as compared to those of compound 1.

Further support of these structures was achieved from the comparison of their spectral data with those of 4 [18], except for an oxymethylene signals observed in 1 instead of a methyl group (Me-21) whereas 2 was a 20-deoxyshidaterone with a hydroxyl group on $\mathrm{C}-11$. The chemical shift $\delta_{\mathrm{H}} 85.3$ for $\mathrm{C}-14$ established an $\mathrm{OH}$ substitution on $\mathbf{1}$ and 2, which is in accordance with a 7en-6-one moiety, showing an HMBC cross-peak with the olefinic $\mathrm{H}-7$ which in turn correlated with two $\mathrm{CH}$ units, $\mathrm{C}-5$ and $\mathrm{C}-9$. The $\mathrm{HMBC}^{2} J$ coupling of the latter methine $\mathrm{H}$-atoms ( $\left.\mathrm{H}-9\right)$ with the $\mathrm{C}-$ atom of the oxo group and the quaternary $\mathrm{C}$-atom in the $\mathrm{sp}^{2}$ hybrid state $\left(\delta_{\mathrm{C}} 122.6\right)$ justified the assignments of the two compounds. The $\mathrm{H}_{\alpha}-9 / \mathrm{H}_{\alpha}-2$ and $\mathrm{Me}-19 / \mathrm{H}_{\beta}-5$ correlations in the NEO spectra of 1 and 2 established a cis-type junction of rings $A$ and $B$ (๑ Fig. 2). Moreover, the presence of $\mathrm{H}_{\beta}-12 / \mathrm{Me}-18, \mathrm{H}_{\beta}-12$ / $\mathrm{CH}_{2} \mathrm{OH}-21$ (1) or Me-21 (2) and $\mathrm{H}_{\alpha}-12 / \mathrm{H}_{\alpha}-17$ cross-peaks and the absence of an $\mathrm{H}_{\alpha}-9 / \mathrm{H}_{\alpha}-15$ correlation verified the trans-type junction of rings $C$ and $D$. The NOESY plots were sufficient to identify the configuration at C-20, but insufficient to identify the configuration at C-22. Fortunately, the absolute configuration $(22 R)$ of 4 has been established [22]. Based on the biogenetic considerations, the intermolecular closure of the furanyl ring from the known precursor 20-hydroxyecdysone followed by oxidation of Me-21 further implied that the stereochemical arrangement of $\mathbf{1}$ and $\mathbf{2}$ must be similar to shidasterone. The structures of $\mathbf{1}$ and $\mathbf{2}$ were thus established as rel. 22R,25-epoxy- $2 \beta, 3 \beta, 14 \alpha, 20 R, 21-$ pentahydroxycholest-7-en-6-one (named 21 hydroxyshidasterone) and rel. $22 R, 25$-epoxy- $2 \beta, 3 \beta, 11 \beta, 14 \alpha$-tetrahydroycholest-7en-6-one (named 11 $\beta$-hydroxy-20-deoxyshidasterone), respectively.

The ${ }^{13} \mathrm{C}$ NMR spectrum of 3 ( $\odot$ Table 2 ) displayed six signals for oxygenated carbons, besides that of the unsaturated ketone. Analysis of mass fragmentation and ${ }^{13} \mathrm{C}$ NMR data of 3 suggested the location of three hydroxyl groups at the side chain of this ecdysteroid. The peak at $m / z 360$ in the mass spectrum of 3 corresponded to the loss of the side chain moiety to give a fragment ion bearing the ecdysteroid rings and a methyl ketal unit. The fragments ions at $m / z 342$ and 300 were due to ions produced by fission between $\mathrm{C}-17$ and $\mathrm{C}-20$ with a loss of one molecule of water and an isopropyl unit, respectively. The assignment of the side chain hydroxyl groups at C-22, C-24, and C-25 was evident from the side chain ions $\mathrm{m} / \mathrm{z} 161$ and 125 derived from cleavage between $\mathrm{C}-17$ and $\mathrm{C}-20$ corresponding to $\mathrm{C}_{8} \mathrm{H}_{17} \mathrm{O}_{3}$ and $\mathrm{C}_{8} \mathrm{H}_{17} \mathrm{O}_{3}-$ $2 \mathrm{H}_{2} \mathrm{O}$, respectively. The ${ }^{13} \mathrm{C}$ NMR spectrum ( Table 1 ) showed that the compound was quite similar to 24-hydroxyecdysone (4) except for three more peaks corresponding to ketal groups observed at $\delta_{\mathrm{C}} 108.6,28.6$, and 27.1 and signals for C-2 and C-3 shifted downfield to $\delta_{\mathrm{C}} 75.1$ and 72.6 , respectively. The molecular mass observed at $\mathrm{m} / \mathrm{z} 520$ was $42 \mathrm{a}$.m. u. higher than the molecular weight of 4 , indicating the additional isopropyl unit to have adjacent diol functionality. For the signal assignment, six of seven methyl signals appearing as singlets were identified in the ${ }^{1} \mathrm{H}$ NMR spectrum ( Table 2). The characteristic ${ }^{2} J_{\mathrm{H}-\mathrm{C}}$ and ${ }^{3} J_{\mathrm{H}-\mathrm{C}}$ HMBC correlations of the methyl groups (isopropyl moiety) were utilised in the assignment. The identification of the germinal methyl Me-26 and Me-27 groups were straightforward owing to their mutual HMBC correlation. A doublet peak $\left[\delta_{\mathrm{H}} 1.41(3 \mathrm{H}, \mathrm{d}\right.$, $J=6 \mathrm{~Hz}$ )] indicated the presence of a secondary methyl group corresponding to 20-deoxyecdysteroid. A fact corroborated by the MS side chain fragment ions $\left(m / z 161,\left[\mathrm{C}_{8} \mathrm{H}_{17} \mathrm{O}_{3}\right]\right)$ and an $\mathrm{HMBC}$ correlation between Me-21 to C-20 ( $\left.\delta_{\mathrm{C}} 40.6\right), \mathrm{C}-17$ ( $\left.\delta_{\mathrm{C}} 51.5\right)$, and in turn to $\mathrm{C}-22\left(\delta_{\mathrm{C}} 77.82\right)$. Differentiation of Me-18 and Me-19 atoms of the angular methyl groups was achieved considering the coupling of the former with $\mathrm{C}-17$ and in turn with $\mathrm{C}-14\left(\delta_{\mathrm{C}}\right.$ 85.7). As predicted by the MS fragment ions, the additional two methyl signals ( $\delta_{\mathrm{H}} 1.19$ and 1.45 both $\mathrm{s}$ ) were assigned to the isopropyl protons confirmed by their mutual HMBC correlation and in turn their ${ }^{2} J_{\mathrm{H}-\mathrm{C}}$ correlation to a quaternary carbon at $\delta_{\mathrm{C}} 108.6$. A series of proton signals at 1.41-2.5 were attributed to resonances of overlapping methylenes and methines of the steroid framework. All of the protonated carbons were assigned by the HSQC experiment. From the foregoing discussion, the structure of 3 was therefore deduced to be 2,3-acetonide-24-hydroxyecdysone. Following the previously established anti-inflammatory activities of the crude extracts from $V$. doniana [8] and preliminary 
Table 3 Effect of ecdysteroids from Vitex doniana stem bark on carrageenan-induced paw oedema.

\begin{tabular}{|c|c|c|c|c|c|c|}
\hline \multirow[t]{2}{*}{ Treatment } & \multicolumn{6}{|c|}{ Increase in paw circumference $(\mathrm{cm})$ and percent inhibition of paw oedema } \\
\hline & $\mathrm{T}_{1 \mathrm{~h}}$ & $\mathrm{~T}_{2 \mathrm{~h}}$ & $T_{3 h}$ & $\mathrm{~T}_{4 \mathrm{~h}}$ & $\mathrm{~T}_{5 \mathrm{~h}}$ & $\mathrm{~T}_{6 \mathrm{~h}}$ \\
\hline$n$-Saline $\mathrm{H}_{2} \mathrm{O}$ & $0.35 \pm 0.02$ & $0.49 \pm 0.09$ & $0.65 \pm 0.09$ & $0.85 \pm 0.06$ & $0.77 \pm 0.07$ & $0.67 \pm 0.08$ \\
\hline Cpd 1 & $\begin{array}{l}0.32 \pm 0.03 \\
(8.57 \%)\end{array}$ & $\begin{array}{l}0.41 \pm 0.03 \\
(16.32 \%)\end{array}$ & $\begin{array}{l}0.36 \pm 0.04^{a} \\
(44.61 \%)\end{array}$ & $\begin{array}{l}0.31 \pm 0.02^{c} \\
(63.52 \%)\end{array}$ & $\begin{array}{l}0.25 \pm 0.01^{c} \\
(67.53 \%)\end{array}$ & $\begin{array}{l}0.21 \pm 0.01 c \\
(68.66 \%)\end{array}$ \\
\hline Cpd 2 & $\begin{array}{l}0.27 \pm 0.02 \\
(22.86 \%)\end{array}$ & $\begin{array}{l}0.33 \pm 0.07 \\
(32.65 \%)\end{array}$ & $\begin{array}{l}0.37 \pm 0.05^{a} \\
(43.08 \%)\end{array}$ & $\begin{array}{l}0.49 \pm 0.04^{a} \\
(42.35 \%)\end{array}$ & $\begin{array}{l}0.35 \pm 0.03^{b} \\
(54.55 \%)\end{array}$ & $\begin{array}{l}0.26 \pm 0.04 \\
(61.19 \%)\end{array}$ \\
\hline Cpd 3 & $\begin{array}{l}0.35 \pm 0.03 \\
(0 \%)\end{array}$ & $\begin{array}{l}0.55 \pm 0.02^{\beta} \\
(32.65 \%)\end{array}$ & $\begin{array}{l}0.37 \pm 0.05^{a} \\
(43.08 \%)\end{array}$ & $\begin{array}{l}0.49 \pm 0.04^{a} \\
(42.35 \%)\end{array}$ & $\begin{array}{l}0.35 \pm 0.03^{b} \\
(54.55 \%)\end{array}$ & $\begin{array}{l}0.26 \pm 0.04 \\
(61.19 \%)\end{array}$ \\
\hline Cpd 4 & $\begin{array}{l}0.24 \pm 0.06 \\
(31.43 \%)\end{array}$ & $\begin{array}{l}0.39 \pm 0.03 \\
(20.41 \%)\end{array}$ & $\begin{array}{l}0.45 \pm 0.03^{a, \alpha} \\
(30.77 \%)\end{array}$ & $\begin{array}{l}0.39 \pm 0.05^{c} \\
(54.11 \%)\end{array}$ & $\begin{array}{l}0.30 \pm 0.04 c \\
(61.03 \%)\end{array}$ & $\begin{array}{l}0.23 \pm 0.05 \\
(65.68 \%)\end{array}$ \\
\hline Cpd 5 & $\begin{array}{l}0.25 \pm 0.01 \\
(28.57 \%)\end{array}$ & $\begin{array}{l}0.27 \pm 0.06^{a} \\
(45.91 \%)\end{array}$ & $\begin{array}{l}0.33 \pm 0.05^{c} \\
(50.64 \%)\end{array}$ & $\begin{array}{l}0.41 \pm 0.04 c \\
(55.76 \%)\end{array}$ & $\begin{array}{l}0.34 \pm 0.05^{c} \\
(55.76 \%)\end{array}$ & $\begin{array}{l}0.25 \pm 0.05^{\circ} \\
(62.68 \%)\end{array}$ \\
\hline Cpd 6 & $\begin{array}{l}0.31 \pm 0.06 \\
(11.43 \%)\end{array}$ & $\begin{array}{l}0.39 \pm 0.07 \\
(20.41 \%)\end{array}$ & $\begin{array}{l}0.47 \pm 0.04^{\alpha} \\
(27.69 \%)\end{array}$ & $\begin{array}{l}0.38 \pm 0.03^{c} \\
(55.29 \%)\end{array}$ & $\begin{array}{l}0.26 \pm 0.04 c \\
(66.23 \%)\end{array}$ & $\begin{array}{l}0.19 \pm 0.05^{c} \\
(71.64 \%)\end{array}$ \\
\hline Cpd 7 & $\begin{array}{l}0.31 \pm 0.03 \\
(11.43 \%)\end{array}$ & $\begin{array}{l}0.27 \pm 0.05^{a} \\
(44.90 \%)\end{array}$ & $\begin{array}{l}0.30 \pm 0.05^{c} \\
(53.85 \%)\end{array}$ & $\begin{array}{l}0.34 \pm 0.05^{c} \\
(60.00 \%)\end{array}$ & $\begin{array}{l}0.32 \pm 0.05 c \\
(58.44 \%)\end{array}$ & $\begin{array}{l}0.28 \pm 0.04 c \\
(58.21 \%)\end{array}$ \\
\hline Diclofenac & $\begin{array}{l}0.32 \pm 0.03 \\
(34.29 \%)\end{array}$ & $\begin{array}{l}0.22 \pm 0.06^{\mathrm{b}} \\
(55.51 \%)\end{array}$ & $\begin{array}{l}0.25 \pm 0.06^{c} \\
(62.15 \%)\end{array}$ & $\begin{array}{l}0.36 \pm 0.05^{c} \\
(58.11 \%)\end{array}$ & $\begin{array}{l}0.32 \pm 0.06^{c} \\
(58.96 \%)\end{array}$ & $\begin{array}{l}0.20 \pm 0.06 \\
(70.14 \%)\end{array}$ \\
\hline
\end{tabular}

Values are mean \pm SEM $(n=5) ;{ }^{a} p<0.05,{ }^{b} p<0.01,{ }^{c} p<0.001$ vs. control; ${ }^{\alpha} p<0.05,{ }^{\beta} p<0.01$ vs. diclofenac 50 mg/kg (two-way ANOVA followed by Bonferroni multiple comparison tests). Figures in parenthesis indicate inhibition (\%) of oedema development. Cpd means compound (100 mg/kg); $0.9 \% \mathrm{normal} \mathrm{saline} \mathrm{water} 10 \mathrm{~mL} / \mathrm{kg}$

finding of the fractions, the anti-inflammatory activities of the isolates were investigated and the results presented in 0 Table 3. Injection of carrageenan into the subplantar tissue of the right hind paws of rats in the control group caused oedema development which peaked $(0.85 \pm 0.06 \mathrm{ml}$ increase in paw volume $)$ at $4 \mathrm{~h}$ post-phlogistic agent injection. The effect of compounds 5 and 7 was significant from the 2 nd to the 6 th $\mathrm{h}$ with a peak effect of up to 62.68 and $60.00 \%$ inhibitions observed at the 6 th and the 4 th h, respectively ( Table 3). The effect of compounds 3 and 6 was significant from the 4 th to the 6 th $\mathrm{h}$ with a peak effect of up to 47.76 and $71.64 \%$ inhibitions observed at the 6 th $h$, respectively ( Table 3). The effects of compounds $\mathbf{1}, \mathbf{2}$, and 4 were significant from the 3rd to the 6th h, with a peak effect of up to 68.66 , 61.19 , and $65.67 \%$ inhibitions observed at the 6 th $\mathrm{h}$, respectively ( Table 3). The peak effects for all the compounds were lesser than, except for 6 (71.64\%), but not significantly different ( $\mathrm{p} \leq 0.05$ ) from that produced by $50 \mathrm{mg} / \mathrm{kg}$ diclofenac $(70.14 \%$ inhibition). The effects of these compounds (1-7) at $100 \mathrm{mg} / \mathrm{kg}$ and diclofenac were all time-dependent all through to the 6 th $\mathrm{h}$ (- Table 3).

The anti-inflammatory effects of the stem bark of $V$. doniana extracts against carrageenan-induced paw oedema noted in this study, coupled with the previously reported anti-inflammatory activities of $V$. doniana stem bark extracts against egg albumeninduced inflammation [13] and leaf extracts against formation of paw oedema inflammation induced by agar in rats [8], may lead to hypothesise potential anti-inflammatory effects of V. doniana extracts. Compounds 1-7, the major isolates from the stem bark, showed inhibitory effects comparable to the effects of diclofenac, a commercially available anti-inflammatory drug. Considering the fact that carrageenan-induced inflammation consists of three distinct phases including an initial release of histamine and serotonin, a second phase mediated by kinins, and a third phase involving prostaglandins [23], the ecdysteroids (1-7) could be inhibiting rat paw oedema development in the middle phase and on the late phase of carrageenan-induced inflammation, which was indicated by the reaction peak mainly after the 4th h. However, doubts exist about the structural requirement for ecdysteroids anti-inflammatory actions, since ecdysteroids with a furan ring side chain (1, 2, and 4) used in this study showed comparable $(p \leq 0.05)$ peak effects to ecdysteroids with a non-cyclised side chain $(3,5,6$, and 7$)$. These results differ from anti-inflammatory results reported previously, where ecdysteroids with a cyclised side chain (polyporoid A and B) exhibited low anti-inflammatory activity, while ecdysteroids a with $\mathrm{OH}$ an group on the side chain had potent anti-inflammatory actions on TPA-induced inflammation [24]. Non-specified ecdysteroids from Pfaffia iresinoids roots did not show appreciable anti-inflammatory activities [25]. A series of ecdysteroids including ajugasterone (5), studied against production of nitric oxide by immune-activated mammalian macrophages, showed a lack of interference in the immunobiological activities of the cells [26]. Such discrepancies in biological activities can be attributed to the fact that minor structural differences could result into major changes in biological activities. Different assay models with different limitations may also cause different trends in bioactivities. Data indicating the effect of these ecdysteroids on prostaglandins release could be valuable in future studies to indicate their bioactivities against inflammation mediators.

\section{Acknowledgements \\ $\nabla$}

Financial assistance by Deutscher Akademischer Austauschdienst (DAAD) through the in-country scholarship to a graduate student (COO) is gratefully acknowledged.

\section{Conflict of Interest \\ $\nabla$}

The authors have declared that there is no conflict of interest among them. 


\section{References}

1 Suksamrarn A, Kumpun S, Yingyongnarongkul B. Ecdysteroids of Vitex scabra stem bark. J Nat Prod 2002; 65: 1690-1692

2 Ono M, Nishida Y, Masuoka C, Li J, Okawa M, Ikeda T, Nohara T. Lignin derivatives and a norditerpene from the seeds of Vitex negundo. J Nat Prod 2004; 67: 2073-2075

3 Sharma RL, Prabhakar A, Dhar KL, Sachar A. A new iridoid glycoside from Vitex negundo Linn (Verbenacea). Nat Prod Res 2009; 23: 12011209

4 Kuruuzum A, Stroch K, Denvirezer O. Glucoside from Vitex agnus castus. Phytochemistry 2003; 63: 959-964

5 Dinan L. Phytoecdysteroids: biological aspects. Phytochemistry 2001; 57: 325-339

6 Meena AK, Singh V, Yadav AK, Singh B, Rao MM. Pharmacological and phytochemical evidence for the extracts from plants of the genus Vitex- a review. Int J Pharm Clin Res 2010; 2: 01-09

7 Sena Filho JG, Duringer J, Maia GLA, Tavares JF, Xavier HS, da Silva MS, da-Cunha EV, Barbosa-Filho JM. Ecdysteroids from Vitex species: distribution and compilation of their ${ }^{13} \mathrm{C}-\mathrm{NMR}$ spectral data. Chem Biodivers 2008; 5: 707-713

8 Iwueke AV, Nwodo OFC, Okoli CO. Evaluation of the anti-inflammatory and analgesic activities of Vitex doniana leaves. Afr J Biotechnol 2006; 5: 1929-1935

9 Irvine FR. Woody plants of Ghana. London: Oxford University Press; $1961 ; 761-762$

10 Kokwaro JO. Medicinal plants of East Africa, 3rd edn. Nairobi, Kenya: University of Nairobi Press; 2009; 152

11 Abdulrahman FI, Onyeyili PA, Sandabe UK, Ogugbuaja VO. Evaluation of the effects of the aqueous extract of Vitex doniana root-bark on the peripheral and central nervous system of laboratory animals. J Appl Sci 2007; 7: 1397-1403

12 Olusola L, Zebulon SC, Okoye FU. Effects of Vitex doniana stem bark on blood pressure. Nig J Nat Prod Med 1997; 1: 19-20

13 Tijjani MA, Abdurahaman FI, Khan IZ, Sandabe UK. Anti-inflammatory, anticonvulsant and antipyretic properties of ethanol extracts of Vitex doniana Sweet stem bark. Int Res J Pharm 2012; 3: 288-292
14 Lorke D. A new approach to practical acute toxicity testing. Arch Toxicol 1983; 54: 275-287

15 Bamgbose SOA, Noamesi BK. Studies on cryptolepine. II: Inhibition of carrageenan-induced oedema by cryptolepine. Planta Med 1981; 42: 392-396

16 Suksamrarn A, Promrangsan N, Chitkul B, Homvisasevongs S, Sirikat A. Ecdysteroids of the root bark of Vitex canescens PII. Phytochemistry 1997; 31: 102-107

17 Coll J, Rexach N, Sanchez-Baeza F, Casas J, Camps J. New ecdysteroids from Polypodium vulgare. Tetrahedron 1994; 50: 7247-7252

18 Lafont R, Harmatha J, Marion-Poll F, Dinan L, Wilson ID. Ecdybase, a free ecdysteroid database. Available at: http://www.ecdybase.org. Accessed January 30, 2012

19 Simon A, Liktor-Busa E, Toth G, Kele Z, Groska J, Bathori M. Additional minor phytoecdysteroids of Serratula wolffii. Helv Chim Acta 2008; 91: $1640-1645$

20 Báthori M, Pongraczi Z. Phytoecdysteroids - from isolation to their effects on humans. Curr Med Chem 2005; 12: 153-172

21 Suksamrarn A, Promrangsan N, Jintasirikul A. Highly oxygenated ecdysteroids from Vitex canescens root bark. Phytochemistry 2000; 53: 921-924

22 Roussel PG, Turner NJ, Dinan L. Synthesis of shidasterone and the unambiguous determination of its configuration at C-22. J Chem Soc Commun 1995; 9: 933-934

23 Vinegar R, Schreiber W, Hugo R. Biphasic development of carrageenan oedema in rats. J Pharmacol Exp Ther 1969; 166: 96-103

24 Sun Y, Yasukawa K. New anti-inflammatory ergostane-type ecdysteroids from the sclerotium of Polyporus umbellatus. Bioorg Med Chem Lett 2008; 18: 3417-3420

25 Taniguchi SF, Bersani-Amado CA, Sudo LS, Assef SMC, Oga S. Effects of Pfaffia iresinoides on the experimental inflammatory process in rats. Phytother Res 1997; 11: 568-571

26 Harmatha J, Vokáč K, Kmoníčkova E, Zídek Z. Lack of interference of common phytoecdysteroids with production of nitric oxide by immune-activated mammalian macrophages. Steroids 2008; 74: 466471 